\title{
THE POTENTIAL OF USING THE BIOLUMINESCENT SYSTEM OF CHAETOPTERUS VARIOPEDATUS TO STUDY FERROPTOSIS IN LIVING ORGANISMS
}

Shcheglov AS $\bowtie$, Tsarkova AS

Shemyakin-Ovchinnikov Institute of Bioorganic Chemistry, Moscow, Russia

Pirogov Russian National Research Medical University, Moscow, Russia

Ferroptosis is a form of programmed cell death associated with iron-dependent lipid peroxidation. Novel ferroptosis inducers and suppressors could be instrumental in developing drugs against neurodegenerative disorders and cancer. Prior to embarking on a search for ferroptosis inducers/suppressors, this form of cell death must be studied in living cells and laboratory animals. In addition to two cofactors, luciferase (or photoprotein) of the parchment tubeworm Chaetopterus variopedatus requires the presence of iron ions and hydrogen peroxide or organic hydroperoxides to exert its activity. Therefore, the bioluminescence system of the parchment tubeworm can be used to study ferroptosis in living organisms.

Keywords: ferroptosis, lipid peroxidation, bioluminescence, luciferase, luciferin, bioimaging, biomedical research, parchment worm, Chaetopterus

Funding: the study was supported by the Russian Science Foundation (Project 18-74-10102).

Acknowledgements: the authors thank the Center for Precision Genome Editing and Genetic Technologies for Biomedicine (Moscow) for their help

Author contribution: Shcheglov AS — study conception, literature analysis, manuscript preparation; Tsarkova AS — literature analysis, manuscript preparation.

$\triangle$ Correspondence should be addressed: Alexander S. Shcheglov

Miklouho-Maclay, 16/10, Moscow, 117997; jukart@mail.ru

Received: 05.05.2021 Accepted: 12.05.2021 Published online: 30.05.2021

DOI: $10.24075 /$ brsmu.2021.024

\section{ПЕРСПЕКТИВЫ ИСПОЛЬЗОВАНИЯ БИОЛЮМИНЕСЦЕНТНОЙ СИСТЕМЫ СНАЕТОРТЕRUS VARIOPEDATUS ДЛЯ МОНИТОРИНГА ФЕРРОПТОЗА В ЖИВЫХ ОРГАНИЗМАХ}

\author{
А. С. Щеглов $\bowtie$, А. С. Царькова
}

Институт биоорганической химии имени М. М. Шемякина и Ю. А. Овчинникова, Москва, Россия

Российский национальный исследовательский медицинский университет имени Н. И. Пирогова, Москва, Россия

\begin{abstract}
Ферроптоз - особый тип программируемой гибели клеток, связанный с интенсивным окислением липидов под действием свободных ионов двухвалентного железа. Новые индукторы и супрессоры ферроптоза могут стать основой для создания препаратов для лечения нейродегенеративных и онкологических заболеваний. Для поиска таких индукторов (супрессоров) ферроптоза необходимо детектировать этот процесс в живых клетках или у лабораторных животных. Люцисераза (фотопротеин) морского дракона Chaetopterus variopedatus для своей активности требует помимо двух кофакторов наличия ионов железа и пероксида водорода (либо органических гидропероксидов). Соответственно биолюминесцентная система морского дракона может быть использована для мониторинга ферроптоза в живых организмах.
\end{abstract}

Ключевые слова: ферроптоз, окисление липидов, биолюминесценция, люцифераза, люцисерин, биоимиджинг, биомедицина, морской дракон, Сhaetopterus Финансирование: исследование выполнено за счет гранта Российского научного фонда (проект № 18-74-10102).

Благодарности: авторы признательны Центру высокоточного редактирования и генетических технологий для биомедицины (Москва) за помощь в проведении исследования.

Вклад авторов: А. С. Щеглов - идея публикации, анализ литературы, написание статьи; А. С. Царькова - анализ литературы, написание статьи.

$\triangle$ Для корреспонденции: Александр Сергеевич Щеглов

ул. Миклухо-Маклая, д. 16/10, г. Москва, 117997; jukart@mail.ru

Статья получена: 05.05.2021 Статья принята к печати: 12.05.2021 Опубликована онлайн: 30.05.2021

DOI: $10.24075 /$ vrgmu.2021.024

\section{Ferroptosis is a new form of programmed cell death}

Programmed cell death is cell death coordinated by specific intracellular mechanisms. It has been described in higher animals, invertebrates, plants, bacteria, and fungi. Programmed cell death plays an immense role in normal organismal development and functioning [1]. It is essential for embryonic development and morphogenesis, tissue remodeling, immune response, elimination of malignant and infected cells. Excessive or insufficient programmed cell death leads to neurodegenerative, autoimmune, oncological and other diseases. The importance of studying programmed cell death was emphasized by two Nobel prizes in physiology and medicine in 2002 and 2016. The first form of programmed cell death to be discovered was apoptosis [2]. Today, at least 10 different nonapoptotic pathways of programmed cell death are known, including autophagy-dependent cell death, necroptosis, ferroptosis, pyroptosis, parthanatos, entosis, NETosis, and some others [1]. Despite extensive research efforts, our knowledge about these processes is still limited.

Ferroptosis is a form of programmed cell death that might hold promise for practical applications. In 2004, it was discovered that a hitherto novel heterocyclic compound erastin caused cell death via a previously unknown nonapoptotic pathway [3]. Erastin directly interacts with mitochondrial voltagedependent anion channels (VDAC) and its action is inhibited by antioxidants, such as $\alpha$-tocopherol, butylated hydroxytoluene and $\beta$-carotene [4]. It is reported that erastin-induced cell death can be prevented by ferrous iron chelators [5]. In 2012, Dickson et al. proposed the term ferroptosis to refer to a new form of cell death associated with intense iron-dependent lipid peroxidation. Genetically, biochemically and morphologically, ferroptosis is distinct from apoptosis, necrosis and autophagiadependent cell death $[1,6]$. Unlike apoptosis, ferroptosis is not 


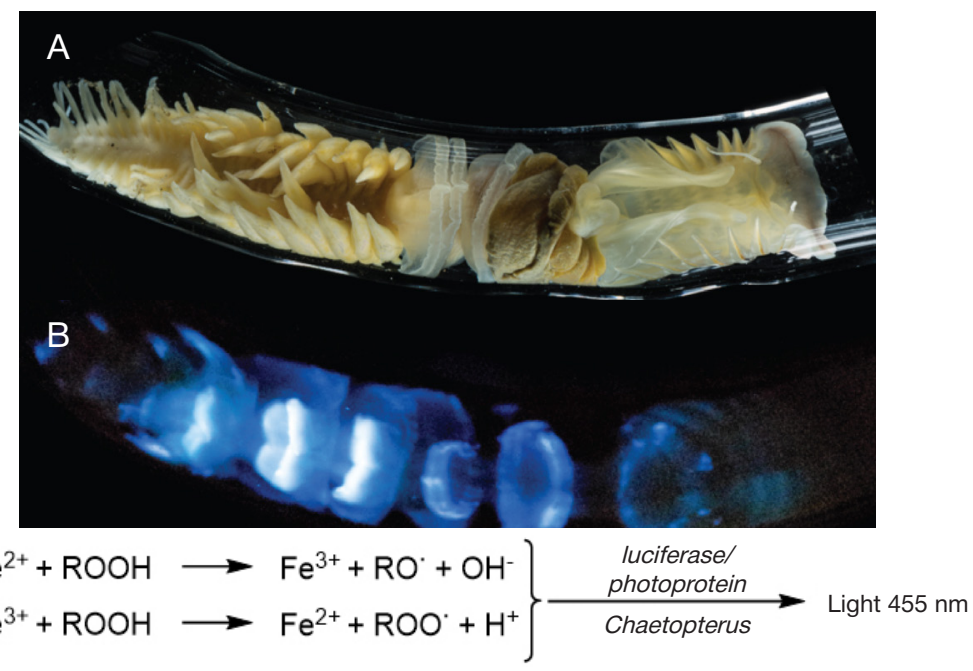

Fig. Bioluminescence of Chaetopterus variopedatus; top: a parchment tubeworm outside of its tube in the light (A) and in the dark (B) (photos provided by Alvaro E. Migotto and Anderson G. Oliveira); bottom: a possible mechanism of bioluminescence (after Mirza JD et al., 2020)

accompanied by cell nucleus transformation and chromatin condensation and is characterized by mitochondrial shrinkage, increased mitochondrial membrane density and vanishing of mitochondrial cristae $[5,6]$. The loss of glutathione peroxidase 4 (GPX4) activity leads to iron-dependent lipid peroxidation and the accumulation of lipid hydroperoxides in the cell, resulting in ferroptotic cell death $[5,7]$. Ferrous ions accumulation and lipid hydroperoxide generation, which cause cell death, are seen in some neurodegenerative disorders, including Alzheimer's disease, Parkinson's disease, Huntington's disease, Friedreich's ataxia, and other pathologies, such as amyotrophic lateral sclerosis, periventricular leukomalacia, ischemic stroke, traumatic brain injury and acute kidney injury. Development and progression of these disorders are thought to be associated with the activation of the ferroptotic cascade [8]. At the same time, ferroptosis appears to be a promising therapeutic strategy for the treatment of apoptosis-resistant malignant tumors, since cancer cells contain increased amounts of ferrous iron. For example, sorafenib, a drug effective against renal cancer, has been shown to induce ferroptosis [9]. Thus, research into the mechanisms underlying ferroptosis and the search for new ferroptosis inducers/suppressors may facilitate the development of novel drugs against neurodegenerative diseases and cancer. However, prior to a large-scale screening of candidate ferroptosis inducers and suppressors, an effective monitoring system is needed to track this process in living cells and laboratory animals.

\section{The promise of the Chaetopterus variopedatus bioluminescent system}

Modern biotechnology and diagnostics actively exploit bioluminescence-based methods characterized by high sensitivity and low background signal. Bioluminescence systems are employed for analyte detection, immunological testing, gene expression analysis, drug screening, bioimaging of living organisms, visualization of intracellular structures and processes, cancer studies and infectious diseases research, and environmental monitoring [10]. Bioluminescence systems are common in nature, but few of them have been well characterized and adapted for practical use. The deciphering of yet understudied bioluminescence systems is instrumental in creating new analytical techniques [11]. One such system is the underinvestigated and unusual bioluminescence system of the parchment tubeworm Chaetopterus variopedatus (see Figure). These benthic filter-feeding organisms inhabit the tube-shaped "homes". When pulled out of the tubes, the worms emit bright blue light and secrete luminescent mucus. The biological role and molecular underpinnings of this mechanism are still not fully clear [12]. According to earlier reports, the activity of Chaetopterus variopedatus photoprotein is dependent on the presence of two cofactors, ferrous iron and hydrogen peroxide or organic hydroperoxides [13]. Later reports demonstrated that the iron-dependent bioluminescent system of the parchment tubeworm functions like the classic "luciferinluciferase" system [14].

As ferroptosis is characterized by simultaneous accumulation of ferrous iron and generation of reactive oxygen species, the ferroptotic cells expressing Chaetopterus variopedatus luciferase would develop a luminescent signal.

\section{Conclusion}

Programmed cell death plays an immense role in normal organismal development and maintenance. Dysregulation of programmed cell death leads to neurodegenerative and autoimmune disorders, cancer, etc. Ferroptosis is a nonapoptotic form of programmed cell death associated with intense iron-dependent lipid peroxidation. Research into the mechanisms underlying ferroptosis and the search for new ferroptosis inducers and suppressors has practical implications. The bioluminescent system of the parchment tubeworm is a promising tool for studying ferroptosis in living laboratory organisms.

\section{References}

1. Tang D, Kang R, Berghe TV, Vandenabeele P, Kroemer G. The molecular machinery of regulated cell death Cell Research 2019 , 29: 347-64, DOI: 10.1038/s41422-019-0164-5.

2. Kerr JF, Wyllie AH, Currie AR. Apoptosis: a basic biological phenomenon with wide-ranging implications in tissue kinetics. $\mathrm{Br}$ J Cancer. 1972; 26 (4): 239-57. DOI: 10.1038/bjc.1972.33. 
3. Dolma S, Lessnick SL, Hahn WC, Stockwell BR. Identification of genotype-selective antitumor agents using synthetic lethal chemical screening in engineered human tumor cells. Cancer Cell. 2003; 3: 285-96. DOI: 10.1016/S1535-6108(03)00050-3.

4. Yagoda N, von Rechenberg M, Zaganjor E, Bauer AJ., Yang WS, Fridman DJ, et al. RAS-RAF-MEK-dependent oxidative cell death involving voltage-dependent anion channels. Nature. 2007; 447: 864-8. DOI: 10.1038/nature05859.

5. Yang WS, Stockwell BR. Synthetic lethal screening identifies compounds activating iron-dependent, nonapoptotic cell death in oncogenic-RAS-harboring cancer cells. Chem Biol. 2008; 15: 234-45. DOI: 10.1016/i.chembiol.2008.02.010.

6. Dixon SJ, Lemberg KM, Lamprecht MR, Skouta R, Zaitsev EM, Gleason CE, et al. Ferroptosis: an iron-dependent form of nonapoptotic cell death. Cell. 2012; 149: 1060-72. DOl: 10.1016/j.cell.2012.03.042.

7. Angeli JPF, Schneider M, Proneth B, Tyurina YY, Tyurin VA, Hammond VJ, et al. Inactivation of the ferroptosis regulator Gpx4 triggers acute renal failure in mice. Nat Cell Biol. 2014; 16: 118091. DOI: $10.1038 /$ ncb3064.

8. Li J, Cao F, Yin H-l, Huang Z-j, Lin Z-t, Mao N, et al. Ferroptosis: past, present and future. Cell Death Dis. 2020; 11 (2): 88. DOI: 10.1038/s41419-020-2298-2.

\section{Литература}

1. Tang D, Kang R, Berghe TV, Vandenabeele P, Kroemer G. The molecular machinery of regulated cell death Cell Research 2019, 29: 347-64, DOI: 10.1038/s41422-019-0164-5.

2. Kerr JF, Wyllie AH, Currie AR. Apoptosis: a basic biological phenomenon with wide-ranging implications in tissue kinetics. $\mathrm{Br}$ J Cancer. 1972; 26 (4): 239-57. DOI: 10.1038/bjc.1972.33.

3. Dolma S, Lessnick SL, Hahn WC, Stockwell BR. Identification of genotype-selective antitumor agents using synthetic lethal chemical screening in engineered human tumor cells. Cancer Cell. 2003; 3: 285-96. DOI: 10.1016/S1535-6108(03)00050-3.

4. Yagoda N, von Rechenberg M, Zaganjor E, Bauer AJ., Yang WS, Fridman DJ, et al. RAS-RAF-MEK-dependent oxidative cell death involving voltage-dependent anion channels. Nature. 2007; 447: 864-8. DOI: 10.1038/nature05859.

5. Yang WS, Stockwell BR. Synthetic lethal screening identifies compounds activating iron-dependent, nonapoptotic cell death in oncogenic-RAS-harboring cancer cells. Chem Biol. 2008; 15: 234-45. DOI: 10.1016/i.chembiol.2008.02.010.

6. Dixon SJ, Lemberg KM, Lamprecht MR, Skouta R, Zaitsev EM, Gleason CE, et al. Ferroptosis: an iron-dependent form of nonapoptotic cell death. Cell. 2012; 149: 1060-72. DOI: 10.1016/j.cell.2012.03.042.

7. Angeli JPF, Schneider M, Proneth B, Tyurina YY, Tyurin VA, Hammond VJ, et al. Inactivation of the ferroptosis regulator Gpx4 triggers acute renal failure in mice. Nat Cell Biol. 2014; 16: 118091. DOI: $10.1038 /$ ncb3064.
9. Yan H-F, Zou T, Tuo Q-Z, Xu S, Li H, Belaidi AA, et al. Ferroptosis: mechanisms and links with diseases. Signal Transduct Target Ther. 2021; 6 (1): 49. DOI:10.1038/s41392-020-00428-9.

10. Syed AJ, Anderson JC. Applications of bioluminescence in biotechnology and beyond. Chem Soc Rev. 2021 Mar 18. DOI: 10.1039/d0cs01492c.

11. Oba Y, Stevani CV, Oliveira AG, Tsarkova AS, Chepurnykh TV, Yampolsky IV. Selected least studied but not forgotten bioluminescent systems. Photochem Photobiol. 2017; 93 (2): 405-15. DOl: 10.1111/php.12704.

12. Mirza JD, Migotto ÁE, Yampolsky IV, de Moraes GV, Tsarkova AS, Oliveira AG. Chaetopterus variopedatus bioluminescence: A review of light emission within a species complex. Photochem Photobiol. 2020; 96 (4): 768-78. DOI: 10.1111/php.13221.

13. Shimomura O, Johnson FH. Chaetopterus photoprotein: crystallization and cofactor requirements for bioluminescence. Science. 1968; 159 (3820): 1239-40. DOI: 10.1126/ science.159.3820.1239.

14. Purtov KV, Petushkov VN, Rodionova NS, Pakhomova VG, Myasnyanko IN, Myshkina NM, et al. Luciferin-Luciferase system of marine polychaete Chaetopterus variopedatus. Dokl Biochem Biophys. 2019; 486 (1): 209-12. DOI: 10.1134/ S1607672919030104.

8. Li J, Cao F, Yin H-I, Huang Z-j, Lin Z-t, Mao N, et al. Ferroptosis: past, present and future. Cell Death Dis. 2020; 11 (2): 88. DOI: 10.1038/s41419-020-2298-2.

9. Yan H-F, Zou T, Tuo Q-Z, Xu S, Li H, Belaidi AA, et al. Ferroptosis: mechanisms and links with diseases. Signal Transduct Target Ther. 2021; 6 (1): 49. DOI:10.1038/s41392-020-00428-9.

10. Syed AJ, Anderson JC. Applications of bioluminescence in biotechnology and beyond. Chem Soc Rev. 2021 Mar 18. DOl: 10.1039/d0cs01492c.

11. Oba Y, Stevani CV, Oliveira AG, Tsarkova AS, Chepurnykh TV, Yampolsky IV. Selected least studied but not forgotten bioluminescent systems. Photochem Photobiol. 2017; 93 (2): 405-15. DOI: 10.1111/php.12704.

12. Mirza JD, Migotto ÁE, Yampolsky IV, de Moraes GV, Tsarkova AS, Oliveira AG. Chaetopterus variopedatus bioluminescence: A review of light emission within a species complex. Photochem Photobiol. 2020; 96 (4): 768-78. DOI: 10.1111/php.13221.

13. Shimomura O, Johnson FH. Chaetopterus photoprotein: crystallization and cofactor requirements for bioluminescence. Science. 1968; 159 (3820): 1239-40. DOI: 10.1126/ science.159.3820.1239.

14. Purtov KV, Petushkov VN, Rodionova NS, Pakhomova VG, Myasnyanko IN, Myshkina NM, et al. Luciferin-Luciferase system of marine polychaete Chaetopterus variopedatus. Dokl Biochem Biophys. 2019; 486 (1): 209-12. DOI: 10.1134/ S1607672919030104 